\title{
Scanning Electron Microscopic Studies on the Growth Features of Mycobacterium lepraemurium in Cell-free Medium
}

\author{
By Z. YOSHII \\ Department of Microbiolog!, Yamaguchi University School of Medicine, Ube, 755, Japan \\ AND M. NAKAMURA \\ Department of Microbiology, Kurume University School of Medicine, Kurume, 830, Japan
}

(Received 2 January 1974)

\begin{abstract}
SUMMARY
The morphology of Mycobacterium lepraemurium, Hawaiian strain, cultivated on a glass slide in a cell-free liquid medium $\left(\mathrm{NC}_{5}\right)$ at $30 \mathrm{C}$ for $\mathrm{I}_{2}$ weeks, was observed every 2 weeks with a scanning electron microscope. Flourishing growth and microcolonial growth occurred in the peripheral and central areas, respectively, of a smear. Elongation, septum formation, division, budding and branching in the bacteria were seen between the second and fourth weeks of incubation, which may correspond to the beginning of the exponential phase. After this period, the number of bacilli suddenly increased, and intertwined, elongated cells with large granules appeared. These features gradually increased until the stationary phase was reached after 12 weeks of incubation. These observations are the first scanning electron microscopical descriptions of the growth patterns of Mycobacterium lepraemurium in vitro.
\end{abstract}

\section{INTRODUCTION}

Mycobacterium lepraemurium, which is a causative agent of so-called murine leprosy, has served as an important model bacterium in the comparative bacteriology and pathology of human leprosy since its discovery by Stefansky (I903). The great difficulty of cultivating this organism in an artificial medium has slowed the development of microbiological research relating to Mycobacterium lepraemurium.

Very recently, however, a cell-free liquid culture medium, referred to as $\mathrm{NC}_{5}$, in which Mycobacterium lepraemurium multiplies beyond doubt, was described by Nakamura (r972, 1973). The cultivated bacilli on glass slides in the NC5 medium were also observed with light and electron microscopes. These studies were reported briefly in previous papers (Nakamura, 1973, I974; Yoshii \& Nakamura, 1973). In the present paper, further information about morphological features of bacilli grown in the $\mathrm{NC}_{5}$ medium and observations with a scanning electron microscope are described.

\section{METHODS}

Strain. We used the Hawaiian strain of Mycobacterium lepraemurium (M56), which has been maintained in Nakamura's laboratory for several years by subcutaneous inoculation into $\mathrm{C}_{3} \mathrm{H}$ mice.

Cultivation. An experimentally developed leproma was excised under sterile condition and a bacillary suspension prepared with sterile distilled water. Tissue fragments and large bacillary clumps were removed by centrifuging at II $7 g$ for $5 \mathrm{~min}$. After several treatments 
with digestive enzymes and chemical agents, as reported previously (Nakamura, 1974), the final suspension of bacilli was prepared in sterile distilled water containing $0.1 \%$ bovine albumin $\mathrm{V}$ fraction (Armour Laboratories).

A drop of the final suspension was smeared on a half-size glass slide, cut lengthwise and coated with silicone. After drying, the smeared slide was immediately placed in the culture medium ( $\mathrm{NC}_{5}$ medium) and incubated at $30^{\circ} \mathrm{C}$. Detailed descriptions of the technical procedures of cultivation have been described in previous papers (Nakamura, 1972, 1973, 1974). The incubated slides were taken out of the culture tubes and examined at $0,2,4,6,8$, Io and 12 weeks.

Scanning electron microscopy. Each cultured slide was prewashed three times with phosphate buffered saline, fixed in $2.0 \%$ glutaraldehyde solution at $4{ }^{\circ} \mathrm{C}$ for $24 \mathrm{~h}$, postwashed three times with phosphate buffered saline, dehydrated through acetone solutions $(50,70,90,95,99$ and $100 \%$ in water), and finally air dried at room temperature. The parts of the slide with bacteria were cut into small pieces, about $8 \times 8 \mathrm{~mm}$, and coated by carbongold evaporation. They were viewed using JSM-SI and JSM-U 3 scanning electron microscopes (Japan Electron Optics Laboratory, Japan) at Io and $15 \mathrm{kV}$ respectively.

\section{RESULTS}

\section{Macroscopic observations}

Bacilli cultivated for $\mathrm{I} 2$ weeks at $30{ }^{\circ} \mathrm{C}$ in the $\mathrm{NC} 5$ medium multiplied abundantly and appeared as a turbid mass macroscopically (Fig. I $a$ ). No change in the smear, however, was seen using enriched Kirchner medium (Kirchner, 1932) which is suitable for the growth of tubercle bacilli.

General features of the smear. Before scanning by electron microscopy, the bacillary distribution in the smear on the glass slide was examined by light microscopy (dark field illumination). Bacilli in the peripheral area were more densely distributed than in the central area. During incubation, the growth of bacilli in the peripheral area was faster and more copious than in the central area. Therefore both areas were examined simultaneously with a scanning electron microscope.

\section{Microscopic observations}

Observations at zero time. Although the distribution of bacilli between the peripheral and central areas of a smear was different, no significant differences in shape and size of the bacteria could be recognized electron-microscopically (Fig. I $b, c$, Fig. 2). The bacilli were slightly curved, stumpy and short rods, and sizes varied between $\mathrm{I} \cdot 3$ and $2.5 \mu \mathrm{m}$ in length and between 0.3 and $0.4 \mu \mathrm{m}$ in width. Some bacteria showed a non-uniform distribution of the cytoplasm with a granular pattern. Arrangements of bacterial cells into V, Y, L, T and other shapes were observed occasionally.

Observations after incubations of 2 and 4 weeks. Elongation of most bacteria had occurred in both areas after 2 weeks' incubation (Fig. 3). After 4 weeks' incubation, the cells were remarkably elongated and were somewhat more slender than resting cells. The longest bacterium seen was about $8.0 \mu \mathrm{m}$ long and $0.3 \mu \mathrm{m}$ wide. On the other hand, most of the unelongated bacteria appeared to be the same shape as the bacteria at zero time. Septum formation, lateral budding, branching and division were also observed after 2 weeks' incubation (Fig. $4 a, b$ ). 'These features became much more marked after 4 weeks' incubation.

Observations after incubations of 6 and 8 weeks. An increase in the number of elongated bacteria was observed, particularly in the peripheral area of the smear, after 6 weeks' 

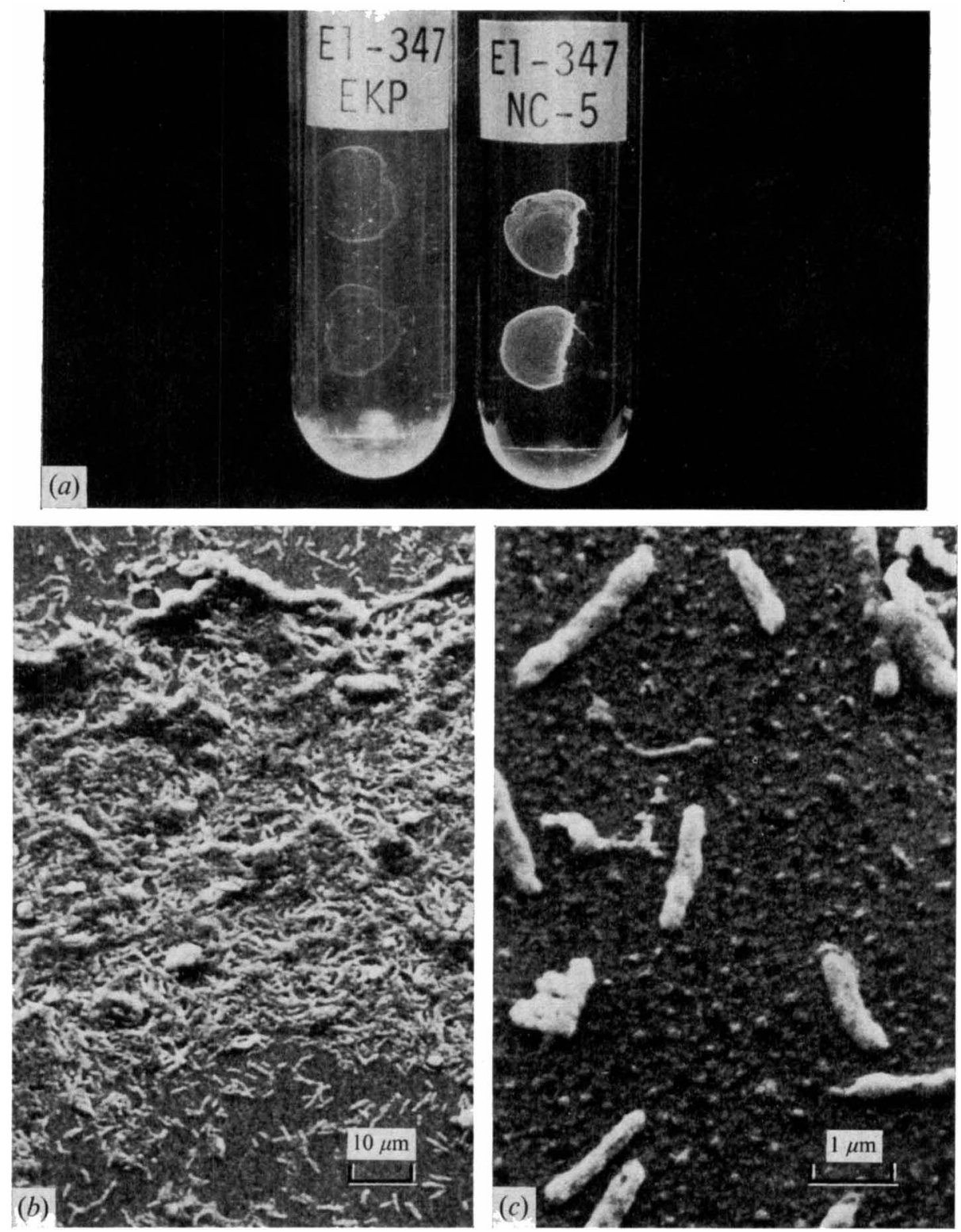

Fig. I. (a) Macroscopic appearance of the bacillary smear cultivated in enriched Kirchner medium (left) and $\mathrm{NC}_{5}$ medium (right) at $30 \mathrm{C}$ for 12 weeks. (b) Scanning electron microscopy of the peripheral area of the smear at zero time. (c) Individual bacteria at zero time.

incubation. The elongated bacteria were intertwined and were so abundant that recognition of the individual bacteria was difficult (Fig. 5); however, the length of the shortest bacterium appeared to be about $5.0 \mu \mathrm{m}$. The width of the bacteria varied from 0.4 to $0.7 \mu \mathrm{m}$.

Large granules of various shapes and sizes were sometimes observed among the flourishing cells in several parts of the peripheral area after 6 or 8 weeks' incubation. Some were 


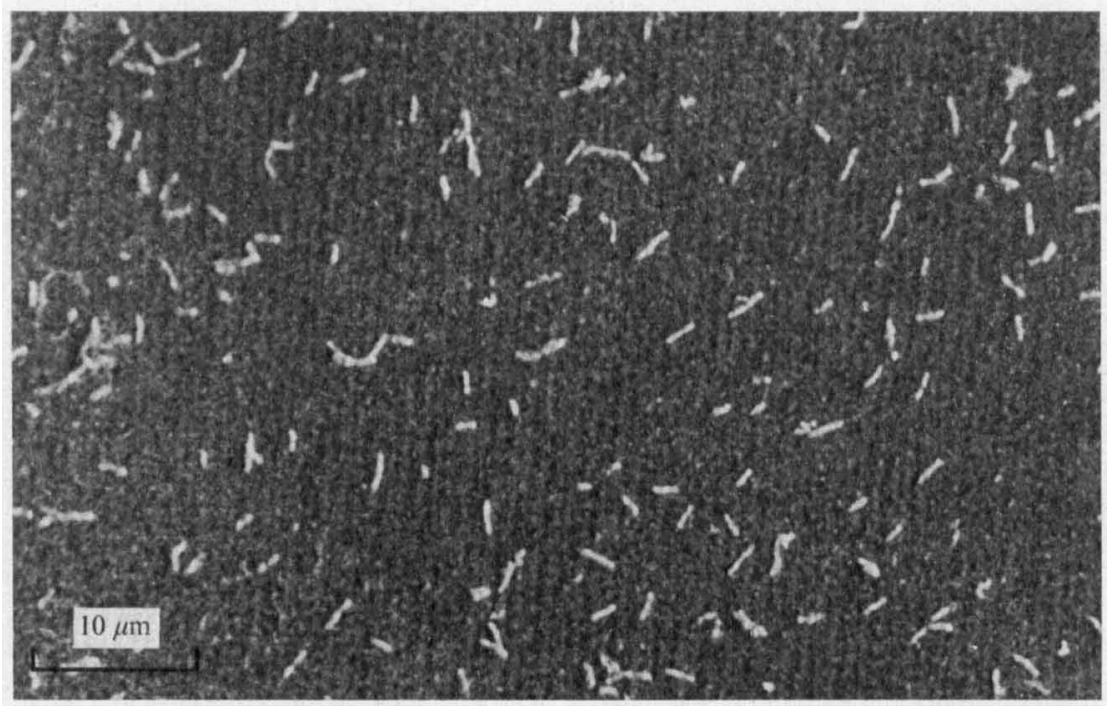

Fig. 2. Scanning electron microscopy of the central area of the smear at zero time.

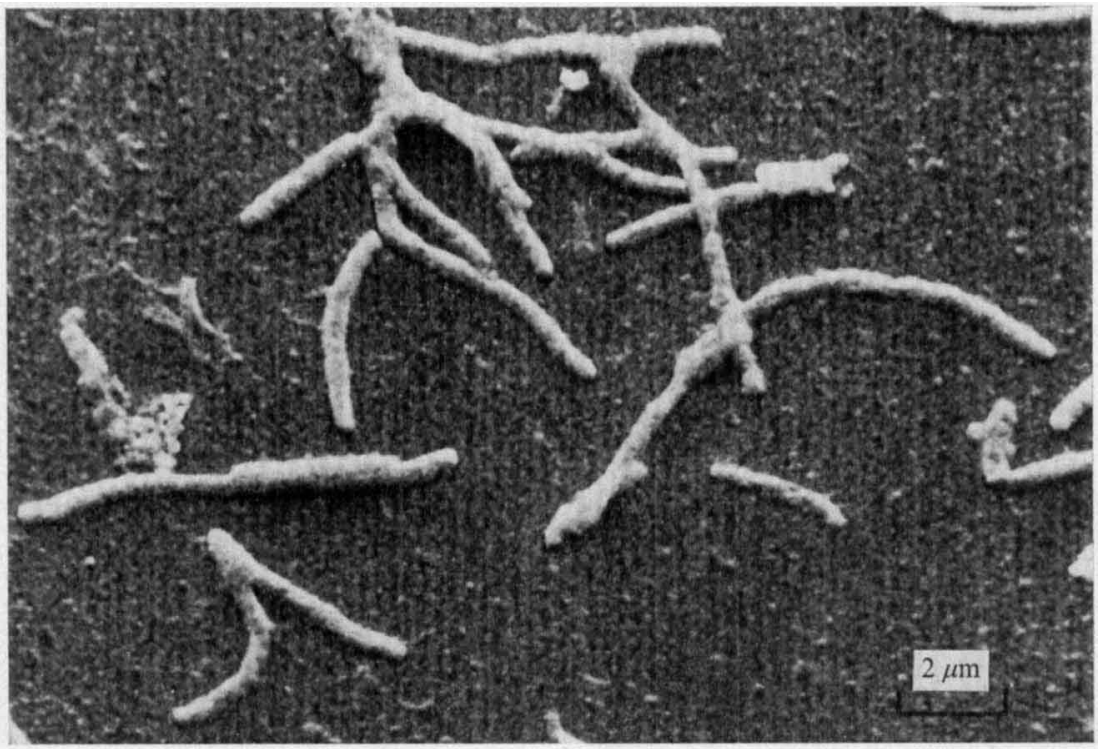

Fig. 3. Scanning electron microscopy of the central area of the smear after cultivation in $\mathrm{NC}_{5}$ medium for 2 weeks.

oval, others round or irregular, with diameters of between $\mathrm{I} \cdot \mathrm{O}$ and $3.0 \mu \mathrm{m}$. The largest one appeared to be an aggregation of bacteria (Fig. 5, upper right).

In the case of the central area of the smear, microcolonial growth of bacilli appeared, with each colony consisting of at least five bacteria (Fig. 6).

Observations after incubations of 10 and $\mathrm{I} 2$ weeks. Abundant, slender bacteria could be seen in the peripheral area at these stages with some bacteria outside the original periphery of the smear. In the central area at these times, microcolonies showed clearer and more 

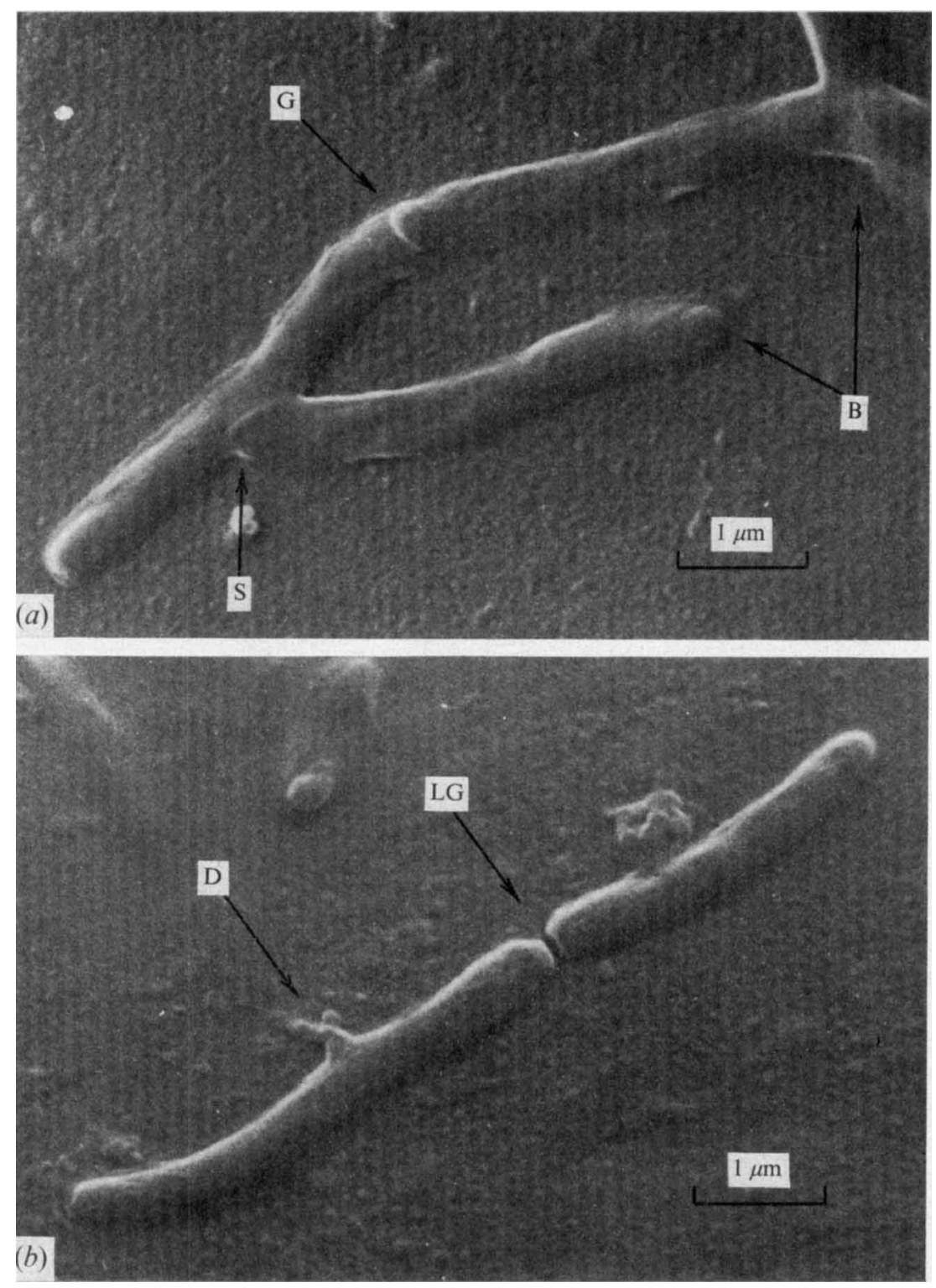

Fig. 4. Mycobacterium lepraemurium after growth in $\mathrm{NC}_{5}$ medium for 2 weeks. G, gemmation; B, branching; S, septum formation; D, division phenomenon; LG, lateral gemmation.

flourishing growth than at earlier stages (Fig. 7). That multiplication of Mycobacterium lepraemurium was occurring on the slide in the $\mathrm{NC}_{5}$ medium can be seen by comparing the microcolonies (Fig. 7) with the bacteria at zero time (Fig. 2). Terminal swelling of bacteria was also seen frequently at these stages (Fig. 8). The morphologically unchanged bacteria, which could still be seen after 12 weeks' incubation (Fig. 7), were probably dead or at least moribund. 


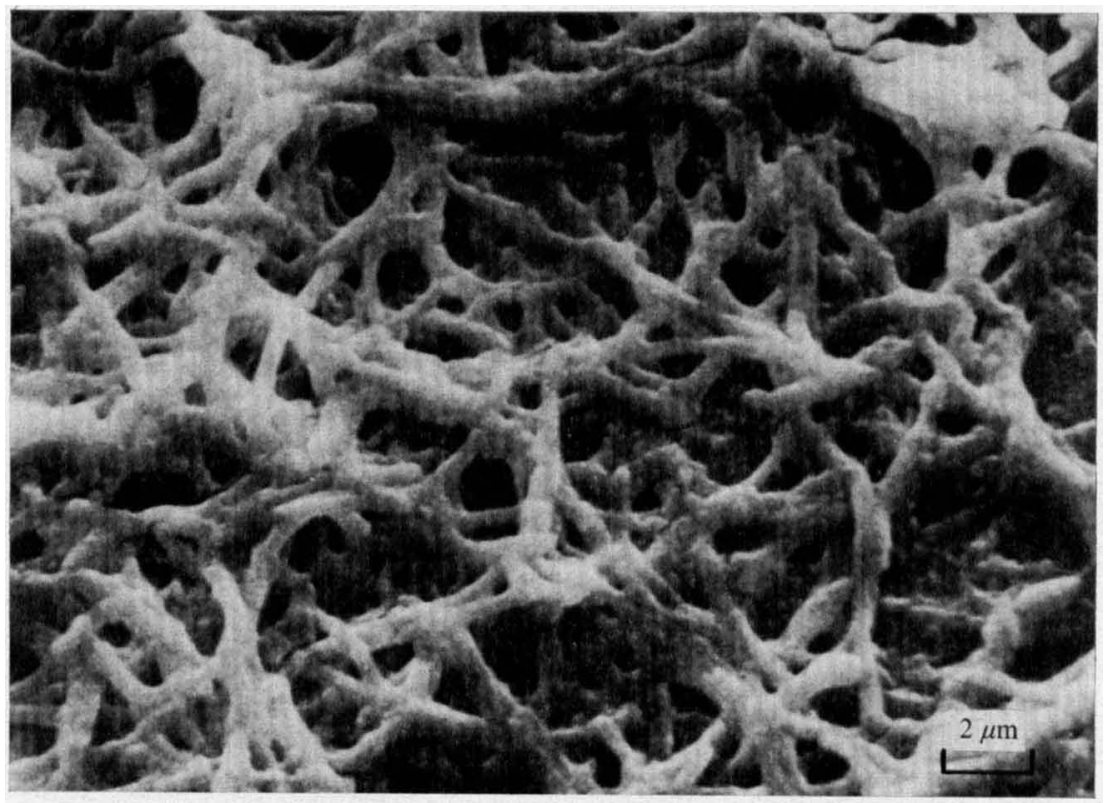

Fig. 5. Mycobacterium lepraemurium in the peripheral area of the smear, after growth in $\mathrm{NC}_{5}$ medium for 8 weeks.

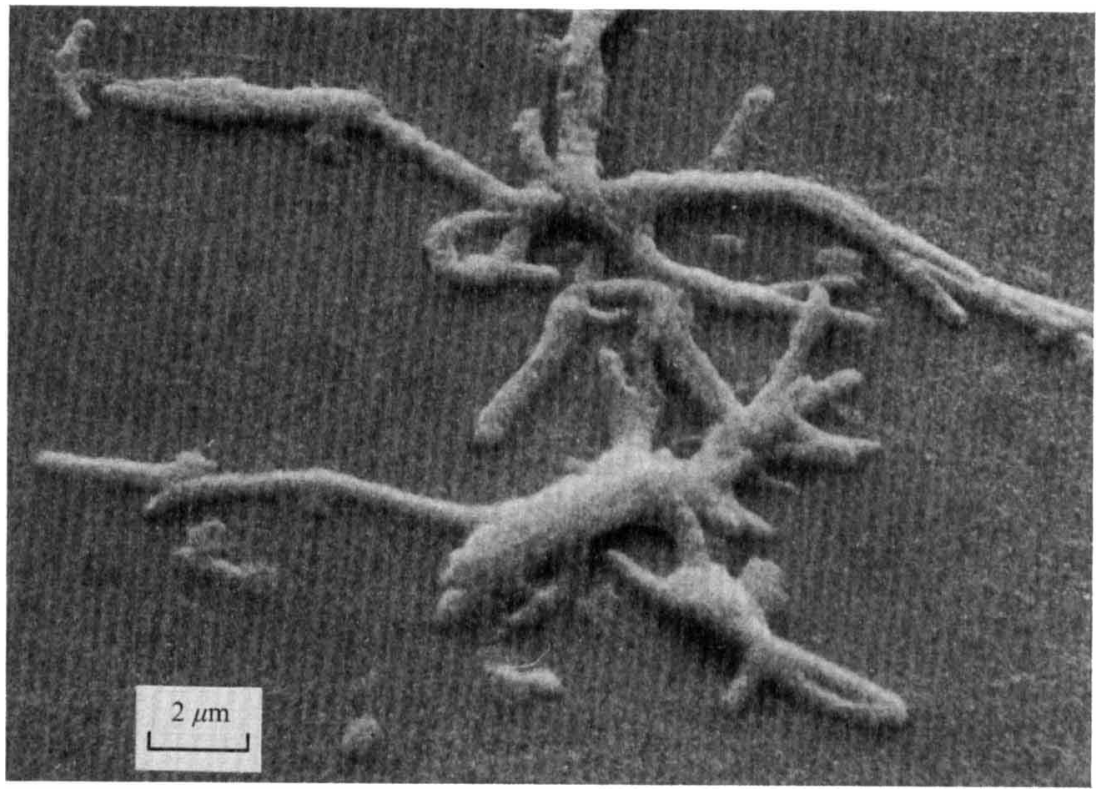

Fig. 6. Mycobacterium lepraemurium in the central area of the smear, after growth in $\mathrm{NC}_{5}$ medium for 8 weeks. 


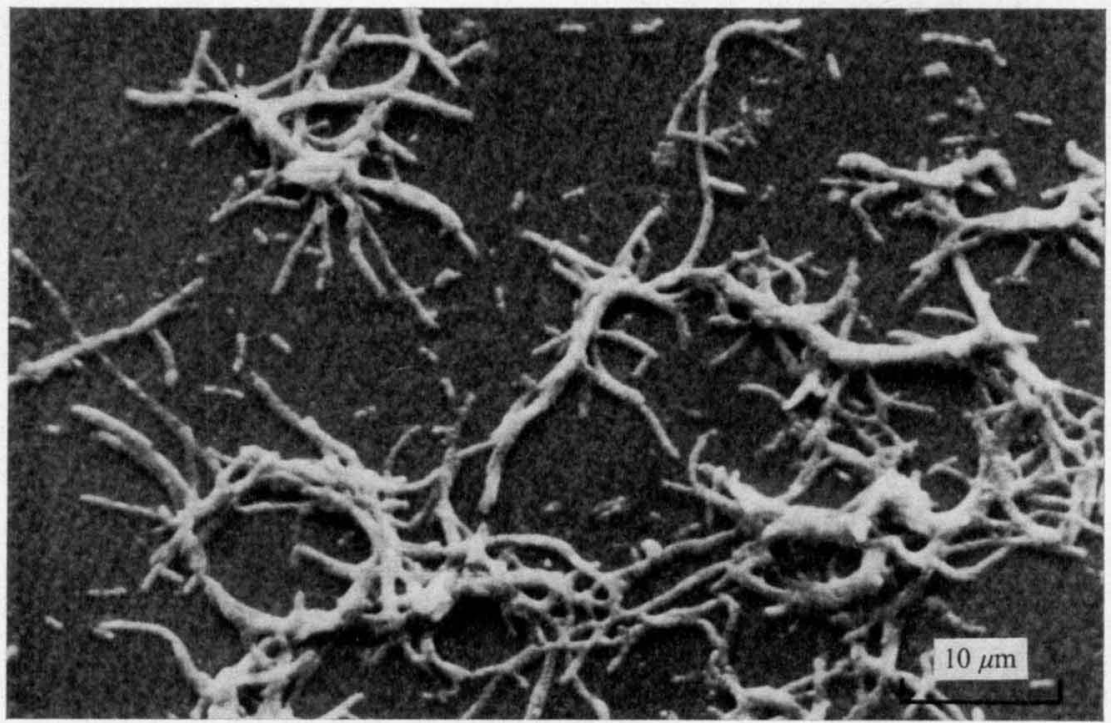

Fig. 7. Microcolony of Mycobacterium lepraemurium in the central area of the smear, cultivated in $\mathrm{NC}_{5}$ medium for 12 weeks.

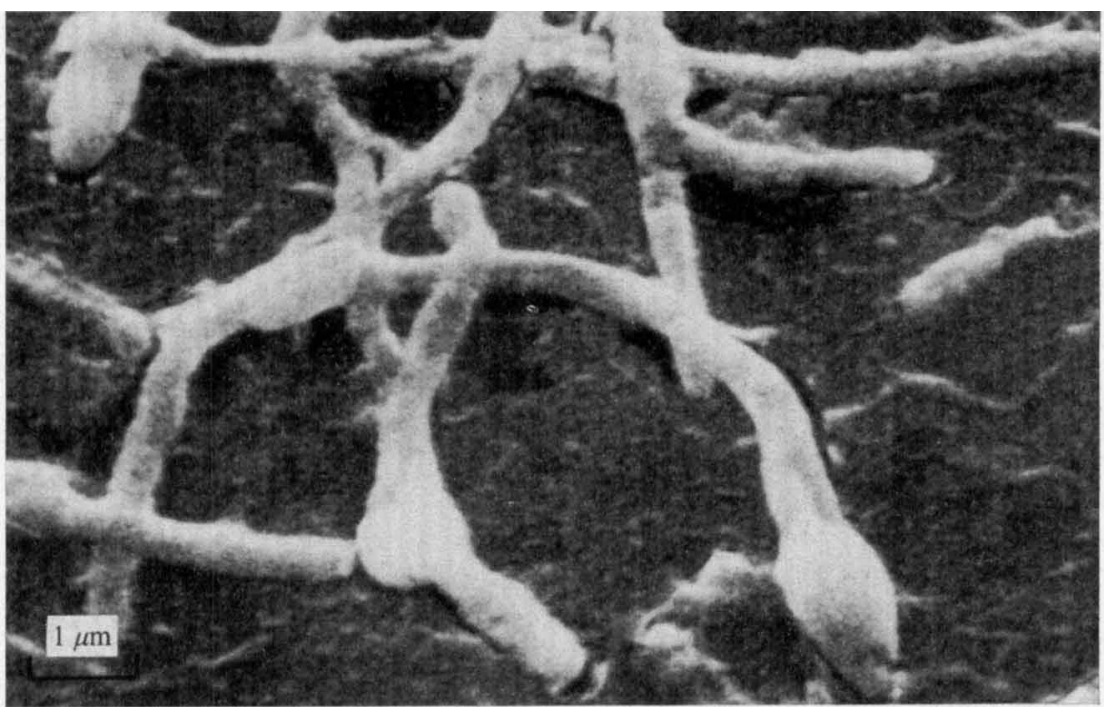

Fig. 8. Terminal swelling of a cell of Mycobacterium leprciemurium cultivated in $\mathrm{NC}_{5}$ medium for 12 weeks.

DISCUSSION

The bacilli elongated to a variety of lengths after 2, 4 and 6 weeks' incubation, suggesting that the bacteria have different viabilities or growth activities. Bacterial multiplication was indicated by septum formation and division. A possible generation time for the organisms in this medium was previously calculated to be about 10 days (Nakamura, 1974). Lateral budding was observed, which might be a beginning of branching (Fig. $4 a, b$ ); it may be 
specific for this bacillus as it has not been observed in other mycobacteria. Although quantitative estimation of bacterial numbers during incubation could not be performed in the slide culture experiments, an apparent sudden increase in the number of bacteria was seen microscopically after 6 weeks' incubation, suggesting that there may be an exponential phase of multiplication between the fourth and sixth weeks of incubation. In suspension culture (Nakamura, I974) the same growth pattern was observed. The lag phase may therefore extend up to 4 weeks from inoculation. The greatest number of bacilli was seen after 8 and Io weeks' incubation, indicating the attainment of a growth maximum or a stationary phase.

Most of the bacilli in the smear on the glass slide formed an annular zone at the outer edge of the smear. This phenomenon was regarded as a meniscus effect occurring during drying. There were, however, great differences between the growth of bacteria in the two areas. Growth in the peripheral zone was faster than in the central area. Luxuriant myceliumlike growth and an enormous number of bacilli were observed 6 weeks after incubation in the former, whereas the scattered bacilli in the latter showed slower growth and the gradual formation of microcolonies. The reason for the discrepancy between the two areas is not clear.

The large granules which sometimes appeared after 6 to 8 weeks' incubation were varied in shape and size. Although they might be artefacts arising during the preparation of specimens for electron microscopy, some of them were similar to the large bodies reported in other bacteria (Stempen \& Hutchinson, I95I $a$, $b$; Knaysi, 195I). The terminal swellings which were sometimes seen in the later stages of growth have also been observed with some nocardia as well as Mycobacterium marianum (Penso, 1964). However, the significance or cause of their appearance is not evident at present.

The authors thank Miss Masayo Okino and Mr. M. Kimoto for their technical assistance. This work was partially aided by a grant from the U.S.-Japan Cooperative Medical Science Program in 1973.

\section{REFERENCES}

KIrChNER, O. (1932). Die Leistungsfähigkeit der Tiefenkultur des Tuberkelbazillus bei Verwendung besonders geeigneter flüssiger Nährboden. Zentralblatt für Bakteriologie, Parasitenkunde, Infektionskrankheiten und Hygiene (Abteilung I) 124, 403-412.

KNAYSI, G. (I95I). The spores of bacteria. In Elements of Bacterial Cytology, pp. 259-260. New York: Comstock.

Nakamura, M. (1972). Multiplication of Mycobacterium lepraemurium in cell-free medium containing a-ketoglutaric acid and cytochrome c. Journal of General Microbiology 73, 193-195.

Nakamura, M. (1973). Multiplication of Mycobacterium lepraemurium in a cell free liquid medium. Proceedings of the Japan Academy 49, 42-46.

NaKamura, M. (1974). Quantitative multiplication of Mycobacterium lepraemurium in a cell-free liquid medium (NC-5). Journal of General Microbiology 82, 385-391.

Penso, G. (1964). In Atlas of Electron Microscopy, Biological Applications. Edited by F. Scanga. Amsterdam: Elsevier.

Stefansky, W. K. (1903). Eine lepra-ähnliche Erkrankung der Haut und der Lymphdrüsen bei Wanderratte. Zentralblatt fiir Bakteriologie, Parasitenkunde, Infektionskrankheiten und Hygiene (Abteilung I) 33, 48I487 .

Stempen, H. \& Hutchinson, W. G. (I95I a). The formation and development of large bodies in Proteus vulgaris ox-19. I. Bright phase contrast observations of living bacteria. Journal of Bacteriology 6r, 32 I335 .

Stempen, H. \& Hutchinson, W. G. (I95 I $b$ ). The formation and development of large bodies in Proteus vulgaris ox-19. II. Comparative cytology of bacilli and large bodies. Journal of Bacteriology 6r, 337-349.

Yoshit, Z. \& NaKamura, M. (1973). Scanning electron microscopy of Mycobacterium lepraemurium cultivated on the slide glass. Proceedings of the Japan Academy 49, 47-50. 